\title{
Study on the Regulation Mechanism of Lipopolysaccharide on Oxidative Stress and Lipid Metabolism of Bovine Mammary Epithelial Cells
}

\author{
Lin LI' ${ }^{1}$, Weibin TANG ${ }^{1}$, Mei ZHAO², Binbin GONG ${ }^{1}$, Meng CAO ${ }^{1}$, Jianyuan LI ${ }^{1}$ \\ ${ }^{1}$ School of Biological Science and Engineering, Xingtai University, Xingtai, China, ${ }^{2}$ Department of \\ Pathology, Xingtai People's Hospital, Hebei Medical University Affiliated Hospital, Xingtai, China
}

Received March 17, 2021

Accepted July 15, 2021

Epub Ahead of Print September 10, 2021

\section{Summary}

The long-term feeding of a high-concentrate diet (the concentrate ratio is greater than $60 \%$ ) leads to mammary gland inflammatory response in ruminants and decreased quality in dairy cows and affects the robust development of the dairy industry. The main reason is closely related to elevated lipopolysaccharide (LPS) in the body. In this experiment, a bovine mammary epithelial cell line (MAC-T) was used as a model, and LPS at different concentrations $(0 \mathrm{ng} / \mathrm{ml}, 1 \mathrm{ng} / \mathrm{ml}, 10 \mathrm{ng} / \mathrm{ml}$, $100 \mathrm{ng} / \mathrm{ml}, 1000 \mathrm{ng} / \mathrm{ml}, 10000 \mathrm{ng} / \mathrm{ml}$ ) was added to the cells. The cell survival rate, oxidative stress indicators, total lipid droplet area, triglyceride content and key genes regulating lipid metabolism were detected by 3-(4,5)-dimethylthiahiazo(-z-y1)3,5-di-phenytetrazoliumromide (MTT), assay kit, microscope observation and RT-PCR methods to explore the regulatory mechanism of mammary health and milk fat synthesis. The results showed that compared with those of the control group, the survival rates of cells were significantly decreased after $9 \mathrm{~h}$ of stimulation with $1000 \mathrm{ng} / \mathrm{ml}$ and $10000 \mathrm{ng} / \mathrm{ml}$ LPS $(P<0.01)$. The contents of superoxide dismutase (SOD), catalase (CAT) and total antioxidant capacity (T-AOC) in cells were significantly decreased $(P<0.05)$. Compared with that of the control group, the content of malondialdehyde (MDA) in cells was significantly increased $(\mathrm{P}<0.05)$ after stimulation with $10000 \mathrm{ng} / \mathrm{ml}$ LPS for $9 \mathrm{~h}$. After $9 \mathrm{~h}$ of stimulation with $100 \mathrm{ng} / \mathrm{ml}, 1000 \mathrm{ng} / \mathrm{ml}$ and $10000 \mathrm{ng} / \mathrm{ml}$ LPS, the total lipid drop area and triglyceride (TG) content of MAC-T cells were significantly decreased $(P<0.05)$. The expression levels of fatty acid synthesis-related genes AcetylCoA carboxylase (ACC) and Stearoyl-CoA desaturase 1 (SCD-1) were significantly decreased after $9 \mathrm{~h}$ of stimulation with $100 \mathrm{ng} / \mathrm{ml}, 1000 \mathrm{ng} / \mathrm{ml}$ and $10000 \mathrm{ng} / \mathrm{ml}$ LPS $(P<0.05)$, while the expression levels of Fatty Acid synthetase (FAS) were significantly decreased after stimulation with $1000 \mathrm{ng} / \mathrm{ml}$ and $10000 \mathrm{ng} / \mathrm{ml}$ LPS $(\mathrm{P}<0.05)$. TG synthesis by the related gene Diacylglycerol acyltransferase-1 (DGAT1) was significantly lower than that of the control group after stimulation with $1000 \mathrm{ng} / \mathrm{ml}$ and $10000 \mathrm{ng} / \mathrm{ml}$ LPS for $9 \mathrm{~h}(\mathrm{P}<0.05)$, and Diacylglycerol acyltransferase-2 (DGAT2) also showed a significant decrease after $10000 \mathrm{ng} / \mathrm{ml}$ LPS stimulation $(P<0.05)$. In conclusion, adding different concentrations of LPS to MAC-T cells not only led to a decrease in cell activity, resulting in oxidative damage, but also affected fatty acid and TG synthesis, which may ultimately be closely related to the decrease in milk fat synthesis.

\section{Key words}

Lipopolysaccharide - MAC-T • Oxidative stress damage • Triglyceride $\bullet$ Fatty acid biosynthesis

\section{Corresponding author}

L. Li, School of Biological Science and Engineering, Xingtai University, Xingtai 054001, China. E-mail: linl1991@163.com

\section{Introduction}

With the continuous improvements in living standards and changes in the nutrition structure, people's eating habits are gradually developing in healthier and more nutritious directions. Milk is a natural nutritional food, and the demand for milk has also changed from quantity to quality. At present, the huge market demand for milk processing products has accelerated the development of the dairy industry. However, during the peak lactation 
period of ruminants, a high-yield performance cannot be met due to the lack of high-quality forage in China (Bush et al. 2020). Therefore, merchants usually increase the proportion of high-concentrate feed in the diet to meet the high energy requirements of lactating cows (Li et al. 2017, Li et al. 2018).

In studies, when the concentrate ratio is greater than $60 \%$, we consider it high-concentrate feeding. Due to the limited effective fiber content in high-concentrate daily food, this often leads to abnormal rumen fermentation in ruminants and body metabolism disorders, resulting in subacute ruminal acidosis (SARA) in ruminants (Orton et al. 2020, Sun et al. 2020). Moreover, high-concentrate feeding can also lead to a decrease in the $\mathrm{pH}$ value in the rumen, and the decreased $\mathrm{pH}$ value causes changes in the rumen environment, changes in microbiome composition and the accumulation of endotoxin (Wu et al. 2016, Isobe et al. 2017). At present, SARA is a problem of great concern to dairy farmers, as it leads to the release of a large amount of abnormal metabolism products, which leads to transfer of lipopolysaccharide (LPS) into the rumen, the blood, and then through the circulation into the dairy milk, causing inflammation, which eventually affects the quality of milk; this is a serious condition that can also lead to hoof lobitis, liver abscess and even death (Khiaosa et al. 2018, Chang et al. 2018, Wang et al. 2019). Therefore, the harm caused by high-concentrate feed has seriously affected the robust development of the dairy industry, and finding a way to control this negative effect is particularly important.

The world's dairy industry has long been challenged by mastitis, a serious inflammatory disease that not only reduces milk production but can also lead to incalculable economic losses. Mammary gland damage in ruminants is often caused by exogenous or endogenous bacterial infection, which triggers the immune response of dairy cows and induces the production of intracellular antigens. Wang et al found that high-concentration diets can activate inflammatory signaling pathway proteins in the mammary glands of lactating dairy cows, which then induces mammary gland injury.

At present, most of the research in this area has focused on in vivo experiments in dairy cows, while there has been little research on mammary gland cells and specific mechanisms in vitro. Therefore, this experiment used bovine mammary epithelial cells as an experimental model. By adding different concentrations of LPS to the cells, the viability of the cells, the damage of oxidative stress, and the specific mechanism of regulating milk fat synthesis were investigated. The prevention and treatment of dairy cow mastitis and improvements in milk quality provide a theoretical basis.

\section{Methods}

\section{Cell culture and reagents}

The bovine mammary epithelial cells line (MACT) were presented by Professor Yuanshu Zhang from Nanjing Agricultural University. MAC-T isolated in our previous research ( $\mathrm{Li}$ et al. 2019) were cultured in complete DMEM/F12 medium were cultured in DMEM ( $10 \%$ fetal bovine serum, $100 \mathrm{U} / \mathrm{ml}$ penicillin, $100 \mathrm{U} / \mathrm{ml}$ streptomycin and $4.5 \mathrm{~g} / \mathrm{l}$ glucose), which was replaced every $24 \mathrm{~h}$, in a cell incubator containing $5 \% \mathrm{CO}_{2}$ at $37^{\circ} \mathrm{C}$. When the confluence reached $80-90 \%$, the cells were digested with a $0.25 \%$ trypsin and $0.02 \%$ EDTA digestive solution and centrifuged at 1500 RPM for 3 min. Then, the supernatant was carefully discarded, and the cells were seeded into 6-well, 12-well and 96-well plates.

\section{Establishment of a MAC-T cell injury model}

\section{3-(4,5-Dimethylthiazol-2-yl)-2,5-diphenyltetrazolium}

bromide (MTT) assay

MAC-T cells were inoculated into 96-well plates $\left(5 \times 10^{4}\right.$ cells/well), and serum-free medium containing different concentrations of LPS $(0 \mathrm{ng} / \mathrm{ml}, 1 \mathrm{ng} / \mathrm{ml}$, $10 \mathrm{ng} / \mathrm{ml}, \quad 100 \mathrm{ng} / \mathrm{ml}, \quad 1000 \mathrm{ng} / \mathrm{ml}, \quad 10000 \mathrm{ng} / \mathrm{ml}$ ) was added. The cells were cultured for $6 \mathrm{~h}$ in a cell incubator containing $5 \% \mathrm{CO}_{2}$ at $37^{\circ} \mathrm{C}$ (pre-experiment results). Then, $20 \mu \mathrm{l} 5 \mathrm{mg} / \mathrm{ml}$ MTT solution was added to each well for another $4 \mathrm{~h}$, the supernatant was discarded, $150 \mu \mathrm{l}$ DMSO solution was added to each well, and the absorbance value at $490 \mathrm{~nm}$ was measured on an RT-6000 semiautomatic biochemical analyzer with a trace oscillator. Eight parallel wells were set up in each group.

Note: According to the results of the MTT test, the optimal stimulation time of LPS-induced inflammatory injury in MAC-T cells was $9 \mathrm{~h}$.

\section{Detection of oxidative stress indicators of MAC-T cells}

When the confluence of the MAC-T cells in 12-well plates reached 70-80 \%, the culture medium was discarded. After washing with PBS, serum-free medium containing LPS at different concentrations $(0 \mathrm{ng} / \mathrm{ml}$, $1 \mathrm{ng} / \mathrm{ml}, 10 \mathrm{ng} / \mathrm{ml}, 100 \mathrm{ng} / \mathrm{ml}, 1000 \mathrm{ng} / \mathrm{ml}, 10000 \mathrm{ng} / \mathrm{ml}$ ) was added. The cells were incubated in a $37{ }^{\circ} \mathrm{C}$ incubator with $5 \% \mathrm{CO}_{2}$ for $9 \mathrm{~h}$, and 6 parallel wells were set up for 
each group. The cells were then harvested, disrupted ultrasonically on ice and centrifuged at $2500 \times \mathrm{g}$ for $10 \mathrm{~min}$ at $4{ }^{\circ} \mathrm{C}$. The supernatants were collected and stored at $-20^{\circ} \mathrm{C}$ until subsequent analysis. The activities of superoxide dismutase (SOD), malondialdehyde (MDA), catalase (CAT), peroxidase (POD) and the total antioxidant capacity (T-AOC) content were determined spectrophotometrically using commercially available assay kits following the manufacturer's instructions (Jiancheng Bioengineering Institute, Nanjing, China), and the data were normalized to the protein concentration as determined by a bicinchoninic acid (BCA) protein assay kit (Jiancheng, Nanjing, China).

\section{Oil Red O staining}

Cells were cultured in 6 -well plates $\left(2 \times 10^{6}\right.$ cells per well) and treated with different concentrations of LPS for $9 \mathrm{~h}$. Briefly, cells were fixed with $10 \%$ buffered formalin for at least $30 \mathrm{~min}$. Next, cells were incubated with $60 \%$ isopropanol for $15 \mathrm{~min}$ at room temperature and stained with Oil Red O solution for another 15 min. Cells were washed 4 times with deionized water and then allowed to air dry. To normalize cell number, cells were counterstained with haematoxylin for $5 \mathrm{~min}$ after Oil Red O staining. Slides were imaged with an optical microscope (Olympus BX53; Tokyo, Japan). Twenty photos were randomly selected from each group, and ten independent visual fields of each photo were used to analyse the count and area of lipid droplets using ImagePro Plus 6.0 software (Media Cybernetics, Silver Spring, MD, USA).

\section{Detection of triglyceride (TG) content}

After incubation with different concentrations of LPS for $9 \mathrm{~h}, \mathrm{MAC}-\mathrm{T}$ cells were collected, and the cells were crushed by an ultrasonic processor. The cells were centrifuged at $4{ }^{\circ} \mathrm{C}$ at $2500 \times \mathrm{g}$ for $10 \mathrm{~min}$, and the supernatant was extracted. The TG content was determined with a triglyceride detection kit (Nanjing Jiancheng Bioengineering Institute, Jiancheng, Nanjing, China).

Expression of mRNA of key genes related to lipid metabolism and TG synthesis in MAC-T cells

After incubation with LPS at different concentrations for $9 \mathrm{~h}$, MAC-T cells were collected, and total RNA was directly extracted from the collected cells by the TRIzol method (Invitrogen, USA). The concentration of total RNA of the samples was measured by a biophotometer, and the purity of total RNA was determined by analysing the $\mathrm{OD}_{260} / \mathrm{OD}_{280}$ values. The $\mathrm{OD}_{260} / \mathrm{OD}_{280}$ value needs to be within the range of 1.8-2.0. One microgram of total RNA was reverse transcribed to obtain cDNA, and the procedures were performed according to the instructions (Promega, USA).

Design of target gene and $\beta$-actin internal marker primers

According to GenBank sequences, primers for Acetyl-CoA carboxylase (ACC), Fatty Acid synthase (FAS), Stearyl-CoA desaturase-1 (SCD-1), Fatty Acid translocase (CD36), Diacylglycerol acyltransferase 1,2 (DGAT1,2) and the $\beta$-actin internal reference genes were designed by Primer Premier 5 software. Primers were synthesized by Shanghai Sangon Co., Ltd. The primer sequences of each gene are shown in Table 1.

Table 1. Prime sequence of targeted gene and $\beta$-Actin.

\begin{tabular}{|c|c|c|c|c|}
\hline Gene & Accession No. & Primers sequence (5'-3’) & Orientation & Product size \\
\hline \multirow[t]{2}{*}{$\beta$-Actin } & NM_001034034 & GCTAACAGTCCGCCTAGAA & Forward & 180 bp \\
\hline & & GCAGTCATCACCATCGGCAATGAG & Reverse & \\
\hline \multirow[t]{2}{*}{ ACC } & XM_005219975.4 & GAGGGTTCAGTTCCAGAAAGTA & Forward & 179 bp \\
\hline & & CCGCCCTGAAATGAGAGATG & Reverse & \\
\hline \multirow[t]{2}{*}{ FAS } & NM_001285629.1 & GCACTACCACAACССАAАCСС & Forward & 161 bp \\
\hline & & CGTTGGAGCCACCGAAGC & Reverse & \\
\hline \multirow[t]{2}{*}{$S C D-1$} & NM_173959.4 & CCGCCCTGAAATGAGAGATG & Forward & 154 bp \\
\hline & & AGGGCTCCCAAGTGTAACAGAC & Reverse & \\
\hline \multirow[t]{2}{*}{ CD36 } & NM_001278621.1 & GACGGATGTACAGCGGTGAT & Forward & 155 bp \\
\hline & & TCAGTGGTAACCAGTTGGAAGT & Reverse & \\
\hline \multirow[t]{2}{*}{ DGAT1 } & XM018058728.1 & AAGCCCTTCAAGGACATG & Forward & 100 bp \\
\hline & & AGAGCCAGTAGAAGAAGATG & Reverse & \\
\hline \multirow[t]{2}{*}{ DGAT2 } & XM_004010192.3 & TTGGTTCTTGTTCACGCTCAC & Forward & 251 bp \\
\hline & & GTAGATTCTGTCTCTGCTTGTTCA & Reverse & \\
\hline
\end{tabular}


Fluorescence quantitative PCR amplification conditions

Fluorescence quantitative PCR was used for analysis, and $2^{-\triangle \triangle \mathrm{CT}}$ was used to calculate the relative expression level of the target mRNA. The PCR conditions were as follows: one cycle at $95^{\circ} \mathrm{C}$ for $3 \mathrm{~min}$, followed by 40 cycles of $95^{\circ} \mathrm{C}$ for $20 \mathrm{~s}, 60{ }^{\circ} \mathrm{C}$ for $30 \mathrm{~s}$ and $72{ }^{\circ} \mathrm{C}$ for $30 \mathrm{~s}$. After the PCR was completed, the specificity of the PCR product was verified by the melting curve, and each sample was repeated three times.

\section{Data analysis and statistics}

All results are expressed as the means \pm the standard error of the mean (SEM). Treatment differences were subjected to Duncan's multiple comparison tests. Differences were considered significant at $\mathrm{P}<0.05$. All statistical analyses were performed with SPSS 13.0 for Windows (SPSS, Chicago, IL).

\section{Results}

Effects of LPS on the cell viability of MAC-T cells

The relative cell viability was determined by an MTT colorimetric assay. The results showed that the relative cell viability started to decrease from $6 \mathrm{~h}$ after the cells were treated with LPS. The relative cell viability in the $1000 \mathrm{ng} / \mathrm{ml} \quad(\mathrm{P}<0.01)$ and $10000 \mathrm{ng} / \mathrm{ml} \quad(\mathrm{P}<0.01)$ groups was significantly lower than that of the control group at $9 \mathrm{~h}$ (Fig. 1). According to the test results, the optimal stimulation time for LPS-induced inflammatory injury of MAC-T cells was $9 \mathrm{~h}$.

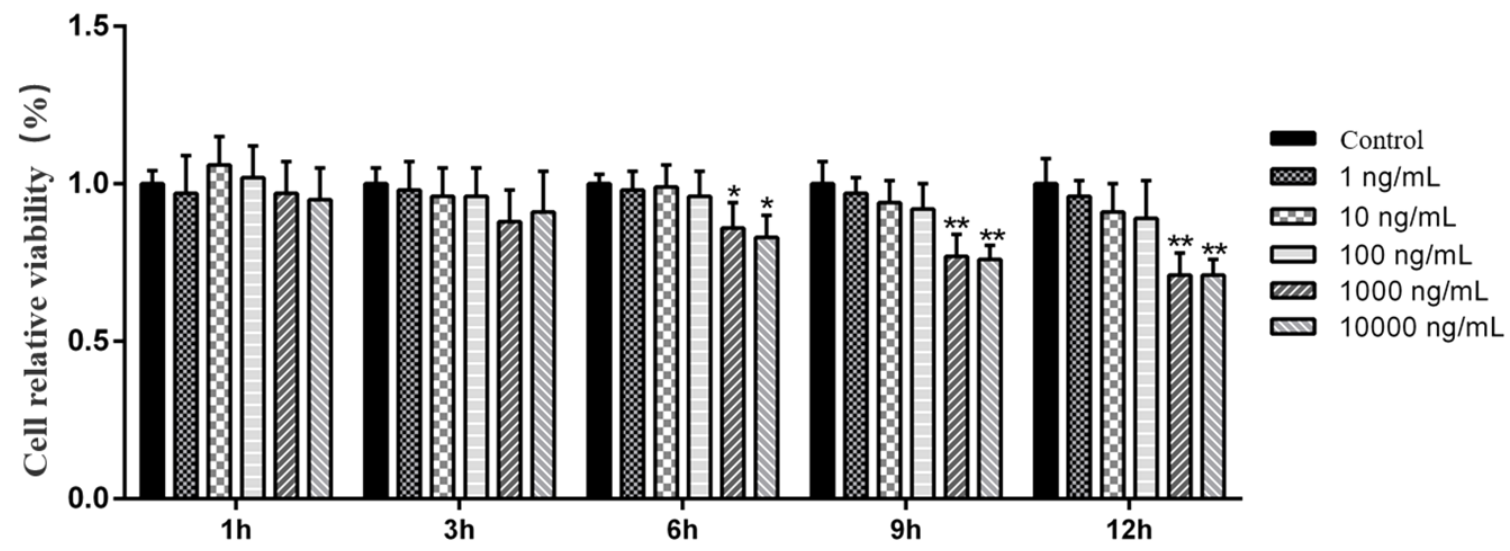

Fig. 1. Effects of LPS on the viability of MAC-T cells after $9 \mathrm{~h}$ of stimulation. Concentration: \%. Data are presented as the means \pm SEM. $* \mathrm{P}<0.05$ and $* * \mathrm{P}<0.01$ compared with the control group $(0 \mathrm{ng} / \mathrm{ml} \mathrm{LPS})$.

Table 2. Effect of lipopolysaccharide (LPS) on the oxidative stress index of MAC-T cells after $9 \mathrm{~h}$ of stimulation.

\begin{tabular}{lcccccc}
\hline Items & Control & $\mathbf{1} \mathbf{~ n g} / \mathbf{m l}$ & $\mathbf{1 0} \mathbf{~ n g} / \mathbf{m l}$ & $\mathbf{1 0 0} \mathbf{~ n g} / \mathbf{m l}$ & $\mathbf{1 0 0 0} \mathbf{~ n g} / \mathbf{m l}$ & $\mathbf{1 0 0 0 0} \mathbf{~ n g} / \mathbf{m l}$ \\
\hline SOD, U/mg prot. & $34.3 \pm 3.16$ & $30.3 \pm 2.12$ & $29.3 \pm 2.17$ & $31.3 \pm 3.51$ & $20.3 \pm 2.36 *$ & $18.3 \pm 2.13^{*}$ \\
MDA, $\mathrm{nmol} / \mathrm{mg}$ prot. & $2.38 \pm 0.29$ & $2.48 \pm 0.19$ & $2.50 \pm 0.41$ & $2.40 \pm 0.34$ & $2.60 \pm 0.24$ & $3.50 \pm 0.32 *$ \\
CAT, U/mg prot. & $5.33 \pm 0.42$ & $5.11 \pm 0.45$ & $4.99 \pm 0.48$ & $5.12 \pm 0.47$ & $4.16 \pm 0.47 *$ & $4.01 \pm 0.46^{*}$ \\
POD, U/mg prot. & $15.12 \pm 1.29$ & $15.11 \pm 1.23$ & $14.93 \pm 1.49$ & $14.83 \pm 1.40$ & $14.74 \pm 1.32$ & $14.89 \pm 1.48$ \\
T-AOC, $\mathrm{U} / \mathrm{ml}$ & $80.1 \pm 8.36$ & $79.2 \pm 7.97$ & $75.6 \pm 7.99$ & $73.7 \pm 8.53$ & $63.3 \pm 5.44^{*}$ & $60.9 \pm 7.11^{*}$ \\
\hline
\end{tabular}

Effect of LPS on the oxidative stress index of MAC-T cells As shown in Table 2, the activities of SOD and T-AOC were significantly decreased $(\mathrm{P}<0.05)$ in the $1000 \mathrm{ng} / \mathrm{ml}$ and $10000 \mathrm{ng} / \mathrm{ml}$ LPS-treated groups compared with the control group. Compared with that in the control group, the MDA content in cells was significantly increased after $9 \mathrm{~h}$ of stimulation with 10000 ng/ml LPS $(\mathrm{P}<0.05)$.
Effect of LPS on lipid droplet accumulation in MAC-T cells

To analyse the distribution of lipid droplets in cells after LPS treatment, Oil Red O staining was used and showed that the total area of lipid droplets was significantly decreased in the $100 \mathrm{ng} / \mathrm{ml}, 1000 \mathrm{ng} / \mathrm{ml}$ and $10000 \mathrm{ng} / \mathrm{ml}$ LPS-treated groups compared to the control group (Fig. 2; $\mathrm{P}<0.05$ ). 


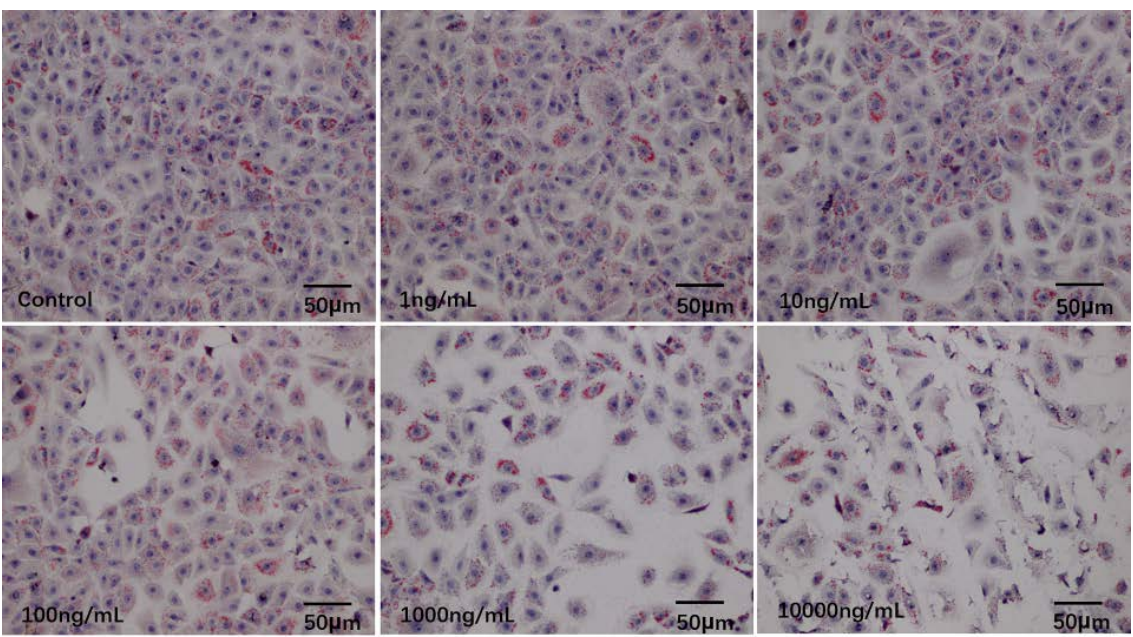

Fig. 2. Effect of LPS on the lipid drop area of MAC-T cells after $9 \mathrm{~h}$ of stimulation. Concentration: $\mathrm{mm}^{2}$. Data are presented as the means \pm SEM. $* \mathrm{P}<0.05$ compared with the control group (0 ng/ml LPS).

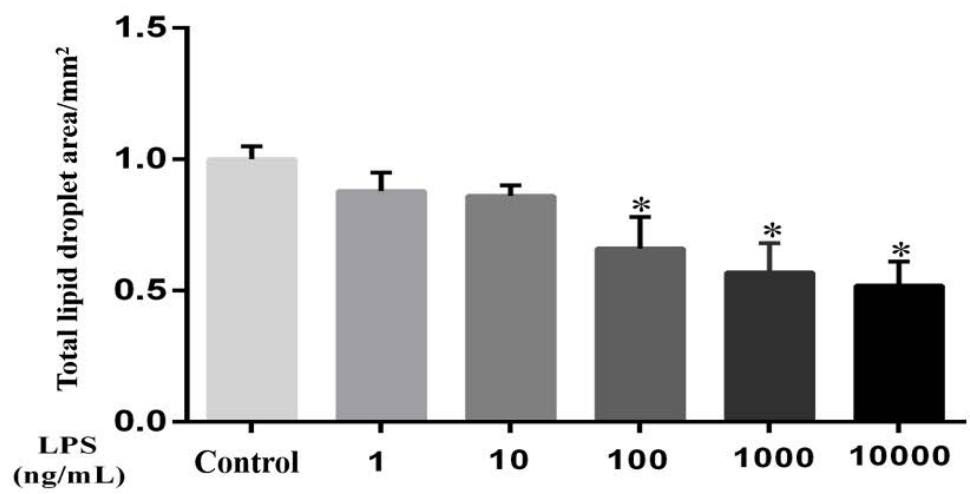

\section{Analysis of TG assay results of MAC-T cells}

As shown in Fig. 3, compared with the control group, the TG content in MAC-T cells was significantly decreased after $9 \mathrm{~h}$ of stimulation with $100 \mathrm{ng} / \mathrm{ml}$, $1000 \mathrm{ng} / \mathrm{ml}$ and $10000 \mathrm{ng} / \mathrm{ml}$ LPS ( $\mathrm{P}<0.05)$. In summary, these results suggest that LPS can reduce lipid production in MAC-T cells and then affect TG production.

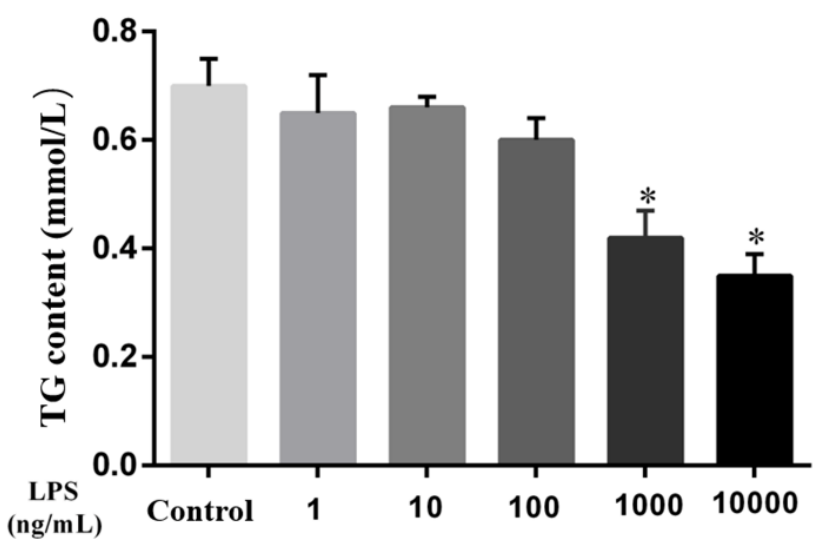

Fig. 3. Effect of LPS on the triglyceride (TG) content of MAC-T cells after $9 \mathrm{~h}$ of stimulation. Concentration: $\mathrm{mmol} / \mathrm{l}$. Data are presented as the means $\pm \mathrm{SEM}$. $* \mathrm{P}<0.05$ compared with the control group ( $0 \mathrm{ng} / \mathrm{ml}$ LPS).
The mRNA expression of enzymes related to lipid metabolism and TG synthesis in MAC-MAC-T cells was affected by LPS

As shown in Fig. 4 and Fig. 5, the mRNA levels of key enzymes of fatty acid activation, transport, and synthesis and TG synthesis in MAC-T cells were assessed. Compared with the control group, the genes related to ACC and SCD-1 were significantly decreased after $9 \mathrm{~h}$ of stimulation with $100 \mathrm{ng} / \mathrm{ml}, 1000 \mathrm{ng} / \mathrm{ml}$ and $10000 \mathrm{ng} / \mathrm{ml}$ LPS $(\mathrm{P}<0.05)$. After $9 \mathrm{~h}$ of $1000 \mathrm{ng} / \mathrm{ml}$ and $1000 \mathrm{ng} / \mathrm{ml}$ LPS stimulation, the FAS gene was also significantly decreased $(\mathrm{P}<0.05)$. Of the related genes that synthesize TG, DGAT1 was significantly decreased compared with the control group after $9 \mathrm{~h}$ stimulation with $1000 \mathrm{ng} / \mathrm{ml}$ and $10000 \mathrm{ng} / \mathrm{ml}$ LPS $(\mathrm{P}<0.05)$, and DGAT2 was decreased significantly after $9 \mathrm{~h}$ stimulation with $10000 \mathrm{ng} / \mathrm{ml}$ LPS $(\mathrm{P}<0.05)$. It is suggested that LPS can affect the de novo synthesis of fatty acids and the content of TG in MAC-T cells, ultimately affecting the production of milk fat.

\section{Discussion}

Milk contains all the nutrients necessary for human growth and metabolism. It provides not only 

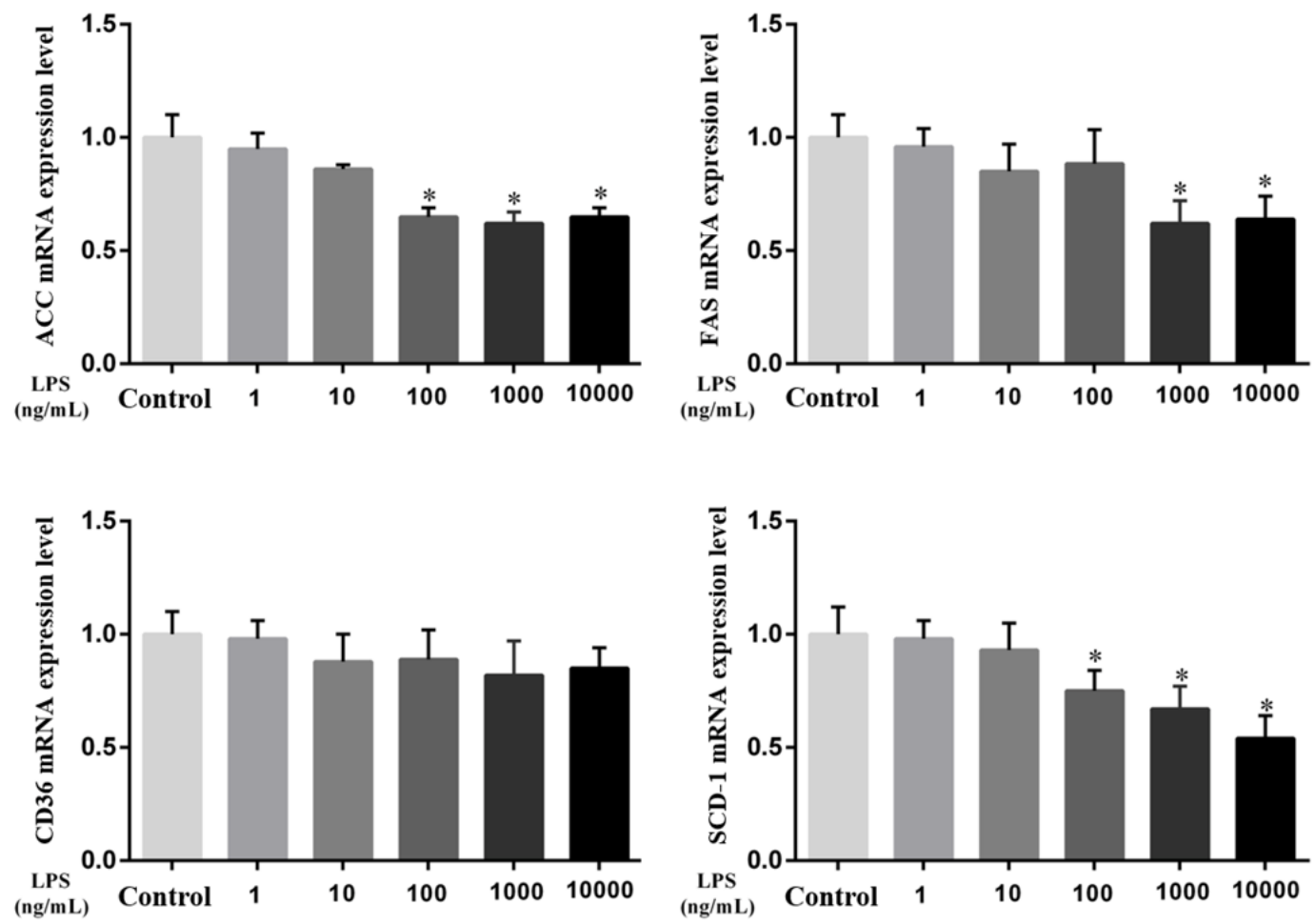

Fig. 4. Effect of LPS on lipid metabolism-related genes in MAC-T cells after $9 \mathrm{~h}$ of stimulation. Acetyl-CoA carboxylase (ACC), Fatty Acid synthase (FAS), Fatty Acid translocase (CD36), Stearyl-CoA desaturase-1 (SCD-1). Data are presented as the means \pm SEM. $* P<0.05$ compared with the control group (0 $\mathrm{ng} / \mathrm{ml}$ LPS).
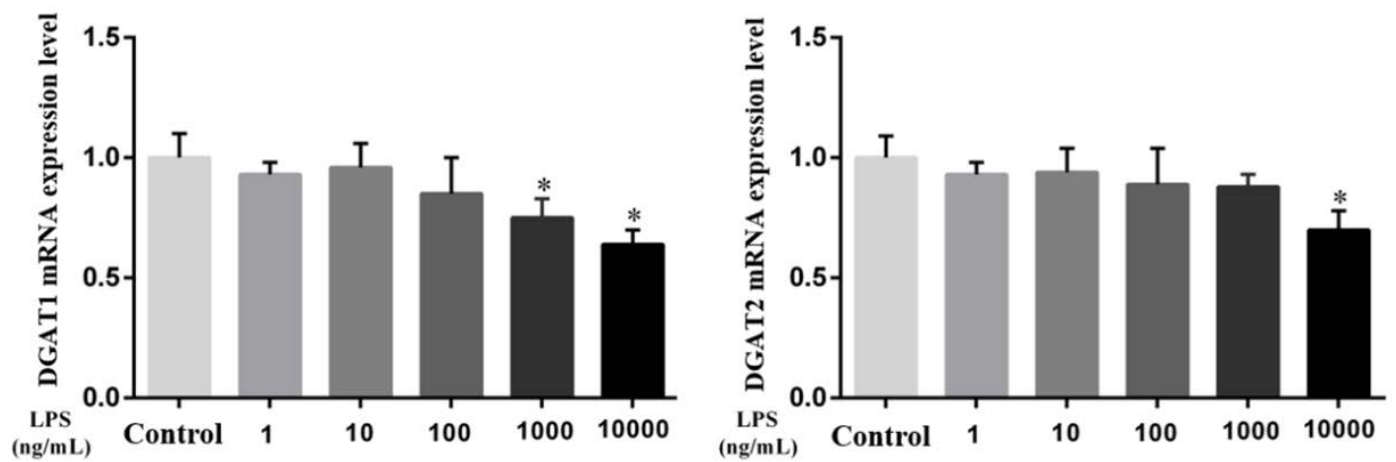

Fig. 5. Effect of LPS on TG biosynthesis-related genes in MAC-T cells after $9 \mathrm{~h}$ of stimulation. Diacylglycerol acyltransferase 1,2 (DGAT1, 2). Data are presented as the means \pm SEM. $* \mathrm{P}<0.05$ compared with the control group $(0 \mathrm{ng} / \mathrm{ml}$ LPS).

calcium but also lipids and proteins that help maintain the balance of nutrients in the body (Hageman et al. 2019). However, SARA induced by high-concentrate feeding can destroy the normal structure of rumen biological flora, resulting in a large number of gram-negative bacteria, and the main pathogenic component of gramnegative bacteria is lipopolysaccharide (Guo et al. 2017, Chang et al. 2018). When high levels of LPS enter the bloodstream, this can cause endotoxaemia and systemic inflammatory reactions (Memon et al. 2019). The cause of mastitis is due to the majority of the main pathogens moving from the milk duct into the mammary gland, which causes inflammation of the mammary gland. Escherichia coli is one of the main pathogens that causes clinical mastitis in dairy cows. Mastitis caused by Escherichia coli usually leads to an impaired milk production function, a sharp increase in somatic cells in milk, a significant decrease in milk yield, and even the death of animals. In this study, compared with the control group, MAC-T cells were stimulated with different concentrations of LPS for 1, 3, 6, 9 and $12 \mathrm{~h}$. The relative survival rate of cells treated with $1000 \mathrm{ng} / \mathrm{ml}$ LPS and $10000 \mathrm{ng} / \mathrm{ml}$ LPS significantly decreased after $6 \mathrm{~h}$, and after 9 and $12 \mathrm{~h}$, there was an extremely significant 
decrease. Therefore, the optimal stimulation time of LPS-induced MAC-T inflammatory injury was $9 \mathrm{~h}$.

LPS, also known as endotoxin, is an outer membrane component of gram-negative bacteria such as Escherichia coli. Studies have found that LPS can change the homeostasis of MECs and improve the expression of inflammatory factors, which can cause serious damage to breast tissue. Current studies have confirmed that when SARA occurs in the body, it often leads to a large amount of LPS in the body, and LPS can enter the breast through the circulating blood and cause oxidative damage to the mammary gland (Li et al. 2018). Oxidation is vital to the body, but excessive oxidation can cause tissue damage. Reactive oxygen species are produced by $\mathrm{O}_{2}$ in a variety of ways. Under healthy conditions, there is a good balance between the formation and transformation of the reactive oxygen (ROS) antioxidant system. However, oxidative stress occurs when ROS production is accelerated or the mechanisms for removing ROS are impaired. When the production of ROS exceeds the antioxidant defence capacity or the optimal level of antioxidants is lacking, these substances may cause oxidative stress. In livestock, several diseases, such as pneumonia and inflammation of the small intestine or mammary glands, are associated with oxidative stress (Hsu et al. 2002, Kelly et al. 2015). Mammary gland oxidative injury and mastitis occur with increases in serum oxidative stress-related indicators, such as MDA, nitric oxide (NO) and inducible nitric oxide synthase (iNOS) (Islam et al. 2017). As an antioxidant protein, SOD can scavenge active oxygen free radicals in a timely manner, which plays a role by reducing the high level of superoxide free radicals induced by extracellular stimuli (such as ultraviolet radiation) (Mosa et al. 2018, Hao et al. 2019, Tan et al. 2019). The MDA content is an indicator of peroxidation of the cell membrane. CAT, an enzyme that catalyses the breakdown of hydrogen peroxide into oxygen and water, is present in the peroxisomes of cells. In this study, after stimulation with $1000 \mathrm{ng} / \mathrm{ml}$ and $10000 \mathrm{ng} / \mathrm{ml}$ LPS for $9 \mathrm{~h}$, the SOD, CAT and T-AOC contents in the cells significantly decreased compared with the control group. However, after $9 \mathrm{~h}$ of stimulation with $10000 \mathrm{ng} / \mathrm{ml}$ LPS, the MDA content in cells significantly increased. These results suggested that LPS not only led to oxidative stress in cells but also caused more cells to undergo abnormal apoptosis.

In ruminants, milk fat synthesis is the main energy cost in milk production and plays a central role in determining the quality of milk products and milk energy distribution. In ruminants, milk fat (3-5\%) is mainly in the form of milk fat globule (MFG, content is $87 \%$ of milk fat). Milk fat globules (diameter 0.1-20 $\mu \mathrm{m}$ ) are composed of nonpolar lipids (mainly TG) encapsulated in a milk fat globule membrane (MFGM) composed of polar lipids. LPS in the blood can be transferred to the mammary gland through the mammary artery, causing damage to the mammary epithelial cells and activating the inflammatory pathway in the mammary gland tissue. This will reduce milk fat synthesis and utilization of breast milk component precursors (fatty acids, glucose, etc.). These precursors are more commonly used to resist the inflammatory state of breast tissue and are consumed, which ultimately leads to a decline in milk quality.

Milk fat synthesis in the mammary gland is a complex biological process. The de initio synthesis of fatty acids involves the activation of acetic acid into acetyl-CoA and then the generation of malonate monoacyl-CoA under the action of ACC. Next, under the action of FAS, the carbon chain is prolonged, and finally, a fatty acid containing 16 carbon atoms is synthesized, after which the carbon chain extension is terminated. In contrast, $\beta$-hydroxybutyric acid is first converted to butyryl coenzyme $\mathrm{A}$, and then the carbon chain is extended (Salie et al. 2016, Kim et al. 2017). ACC is the first key enzyme that catalyses the de novo synthesis of fatty acids from the substrate acetyl-CoA. FAS is a key metabolic enzyme for the de initio growth of the chain of the fatty acids in the presence of the reducing substrate nicotinamide adenine dinucleotide phosphate (NADPH), which plays a key role in the regulation of energy, metabolism and balance in the body. SCD is a key medium in fatty acid biosynthesis (Zhu et al. 2018, Conte et al. 2010). Milk TG composition can also be influenced by genetic factors. Milk fat TG is synthesized via the glycerol-3-phosphate pathway, where the enzyme DGAT1 is of interest because of its role in the final step of triglyceride synthesis and because it is polymorphic in many dairy cattle populations (Huang et al. 2021, Xu et al. 2016). Moreover, previous studies have shown that during lactation in mammals, the key enzymes involved in fatty acid synthesis in mammary epithelial cells are significantly upregulated.

In this experiment, compared with the control group, the total content of lipid droplets and the content of TG in MAC-T cells were significantly decreased after $9 \mathrm{~h}$ of stimulation with $100 \mathrm{ng} / \mathrm{ml}, 1000 \mathrm{ng} / \mathrm{ml}$ and $10000 \mathrm{ng} / \mathrm{ml}$ LPS. The mRNA expression levels of key genes in fatty acid synthesis, including ACC and SCD-1, 
were significantly decreased after $9 \mathrm{~h}$ of $100 \mathrm{ng} / \mathrm{ml}$, $1000 \mathrm{ng} / \mathrm{ml}$ and $10000 \mathrm{ng} / \mathrm{ml}$ LPS stimulation compared with the control group. In addition, FAS expression was significantly decreased after stimulation with $1000 \mathrm{ng} / \mathrm{ml}$ and $10000 \mathrm{ng} / \mathrm{ml}$ LPS. The study of TG synthesis-related enzymes found that the DGAT1 expression levels after stimulation with $1000 \mathrm{ng} / \mathrm{ml}$ and $10000 \mathrm{ng} / \mathrm{ml} \mathrm{LPS} \mathrm{for}$ $9 \mathrm{~h}$ were significantly decreased, and the DGAT2 expression level also showed a significant decrease after stimulation with $10000 \mathrm{ng} / \mathrm{ml}$ LPS for $9 \mathrm{~h}$. It is suggested that LPS can decrease the TG content in MAC-T cells and affect the activities of the lipid synthesis pathway and key enzymes of TG synthesis. This results in a decrease in TG content, which affects the synthesis of milk fat.

In summary, the results of this study showed that the addition of LPS to MAC-T cells caused not only a decrease in cell activity but also cell oxidative damage. Adding different concentrations of LPS to MAC-T cells not only caused a decrease in cell activity, resulting in cell oxidative damage, but also affected fatty acid and TG synthesis, which may ultimately be closely related to the decrease in milk fat synthesis.

\section{Conflict of Interest}

There is no conflict of interest.

\section{Acknowledgements}

This work was supported by the Hebei Youth Natural Science Foundation (C2020108002).

\section{References}

BUSH SJ, MCCULLOCH MEB, LISOWSKI ZM, MURIUKI C, HUME DA: Species-specificity of ranscriptional regulation and the response to lipopolysaccharide in mammalian macrophages Front Cell Dev Biol 8: 661, 2020. https://doi.org/10.3389/fcell.2020.00661

CHANG G, YAN J, MA N, LIU X, DAI H, BILA LMS, SHEN X: Dietary sodium butyrate supplementation reduces high-concentrate diet feeding-induced apoptosis in mammary cells in dairy goats. J Agric Food Chem 66: 2101-2107, 2018. https://doi.org/10.1021/acs.jafc.7b05882

CHANG G, WANG L, MA N, ZHANG WW, ZHANG HM, DAI HY, SHEN XZ: Histamine activates inflammatory response and depresses casein synthesis in mammary gland of dairy cows during SARA. BMC Vet Res 14: 1-9, 2018. https://doi.org/10.1186/s12917-018-1491-3

CONTE G, MELE M, CHESSA S, CASTIGLIONI B, SERRAA, PAGNACCO G: Diacylglycerol acyltransferase 1, stearoyl-CoA desaturase 1, and sterol regulatory element binding protein 1 gene polymorphisms and milk fatty acid composition in italian brown cattle. J Dairy Sci 93: 753-763, 2010. https://doi.org/10.3168/jds.2009-2581

GUO J, CHANG G, ZHANG K, XU L, JIN D, BILAL MS, SHEN X: Rumen-derived lipopolysaccharide provoked inflammatory injury in the liver of dairy cows fed a high-concentrate diet. Oncotarget 8: 46769, 2017. https://doi.org/10.18632/oncotarget.18151

HAGEMAN J HJ, DANIELSEN M, NIEUWENHUIZEN AG, FEITSMA AL, DALSGAARD TK: Comparison of bovine milk fat and vegetable fat for infant formula: Implications for infant health. Int Dairy J 92: 37-49, 2019. https://doi.org/10.1016/j.idairyj.2019.01.005

HAO M, LIU R: Molecular mechanism of CAT and SOD activity change under MPA-CdTe quantum dots induced oxidative stress in the mouse primary hepatocytes. Spectrochim Acta A Mol Biomol Spectrosc 220: 117104, 2019. https://doi.org/10.1016/j.saa.2019.05.009

HSU HY, WEN MH: Lipopolysaccharide-mediated reactive oxygen species and signal transduction in the regulation of interleukin-1 gene expression. J Biol Chem 277: 22131-22139, 2002. https://doi.org/10.1074/jbc.M111883200

HUANG JS, GUO BB, LIN FF, ZENG LM, WANG HY: A novel low systemic diacylglycerol acyltransferase 1 inhibitor, Yhhu2407, improves lipid metabolism. Eur J Pharm Sci 158: 105683, 2021. https://doi.org/10.1016/j.ejps.2020.105683

ISLAM MT: Oxidative stress and mitochondrial dysfunction-linked neurodegenerative disorders. Neurol Res 39: 73-82, 2017. https://doi.org/10.1080/01616412.2016.1251711

ISOBE N: Control mechanisms for producing antimicrobial factors in ruminant mammary gland. Anim Sci J 88: 937-943, 2017. https://doi.org/10.1111/asj.12808 
KHIAOSA-ARD R, ZEBELI Q: Diet-induced inflammation: From gut to metabolic organs and the consequences for the health and longevity of ruminants. Res Vet Sci 120: 17-27, 2018. https://doi.org/10.1016/j.rvsc.2018.08.005

KELLY B, TANNAHILL GM, MURPHY MP, LUKE AJ: Metformin inhibits the production of reactive oxygen species from NADH: ubiquinone oxidoreductase to limit induction of interleukin-1 $\beta$ (IL-1 $\beta$ ) and boosts interleukin-10 (IL-10) in lipopolysaccharide (LPS)-activated macrophages. J Biol Chem 290: 20348-20359, 2015. https://doi.org/10.1074/jbc.M115.662114

KIM CW, ADDY C, KUSUNOKI J, ANDERSON NN, DEJAS, FU X, BURGESS SC, LI C, RUDDY M, CHAKRAVARTHY M: Acetyl CoA carboxylase inhibition reduces hepatic steatosis but elevates plasma triglycerides in mice and humans: a bedside to bench investigation. Cell Metab 26: 394-406, 2017. https://doi.org/10.1016/j.cmet.2017.07.009

LI L, CAO Y, XIE ZL, ZHANG Y: A high-concentrate diet induced milk fat decline via glucagon-mediated activation of AMP-activated protein kinase in dairy cows. Sci Rep 7: 44217, 2017. https://doi.org/10.1038/srep44217

LI L, HE ML, LIU Y, ZHANG YS: Buffering agent induced lactose content increases via growth hormone mediated activation of gluconeogenesis in lactating goats. Physiol Res 67: 317-329, 2018. https://doi.org/10.33549/physiolres.933715

LI L, HE ML, WANG K, ZHANG YS: Buffering agents via insulin-mediated activation of PI3K/AKT signaling pathway to regulate lipid metabolism in lactating goats. Physiol Res 67: 753-764, 2018. https://doi.org/10.33549/physiolres.933698

LI L, WANG HH, NIE XT, JIANG WR,| ZHANG YS: Sodium butyrate ameliorates lipopolysaccharide -induced cow mammary epithelial cells from oxidative stress damage and apoptosis. J Cell Biochem 120: 2370-2381, 2019. https://doi.org/10.1002/jcb.27565

MEMON MA, WANG Y, XU T, MA NN: Lipopolysaccharide induces oxidative stress by triggering MAPK and Nrf2 signalling pathways in mammary glands of dairy cows fed a high-concentrate diet. Microb Pathog 128: 268-275, 2019. https://doi.org/10.1016/j.micpath.2019.01.005

MOSA KA, EL-NAGGAR M, RAMAMOORTHY K, ALAWADHI H, HANI H: Copper nanoparticles induced genotoxicty, oxidative stress, and changes in superoxide dismutase (SOD) gene expression in cucumber (Cucumis sativus) plants. Front Plant Sci 9: 1-13, 2018. https://doi.org/10.3389/fpls.2018.00872

ORTON T, ROHN K, BREVES G, BREDE M: Alterations in fermentation parameters during and after induction of a subacute rumen acidosis in the rumen simulation technique. J Anim Physiol Anim Nutr 104: 1678-1689, 2020. https://doi.org/10.1111/jpn.13412

SALIE MJ, THELEN JJ: Regulation and structure of the heteromeric acetyl-CoA carboxylase. Biochim Biophys Acta 1861: 1207-1213, 2016. https://doi.org/10.1016/j.bbalip.2016.04.004

SUN X, LUO S, JIANG C, TANG Y, XU C: Sodium butyrate reduces bovine mammary epithelial cell inflammatory

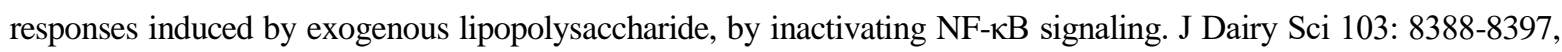
2020. https://doi.org/10.3168/jds.2020-18189

TAN K, ZHANG B, MA H, LI S, ZHENG H: Oxidative stress responses of golden and brown noble scallops Chlamys nobilis to acute cold stress. Fish Shellfish Immunol 95: 349-356, 2019. https://doi.org/10.1016/j.fsi.2019.10.047

WU T, WANG C, DING L, SHEN Y, CUI H, WANG M, WANG H: Arginine relieves the inflammatory response and enhances the casein expression in bovine mammary epithelial cells induced by lipopolysaccharide. Mediators Inflamm 2016: 1-10, 2016. https://doi.org/10.1155/2016/9618795

WANG Y, ZHANG W, MA N, WANG LL, DAI HY, BILAL MS, ANIMESH CR, SHEN XZ: Overfeeding with a high-concentrate diet activates the NOD1-NF- $\kappa B$ signalling pathway in the mammary gland of mid-lactating dairy cows. Microb Pathog 128: 390-395, 2019. https://doi.org/10.1016/j.micpath.2019.01.038

XU HF, LUO J, ZHAO WS, YANG YC, TIAN HB, SHI HB, BIONAZ M: Overexpression of SREBP1 (sterol regulatory element binding protein 1) promotes de novo fatty acid synthesis and triacylglycerol accumulation in goat mammary epithelial cells. J Dairy Sci 99: 783-795, 2016. https://doi.org/10.3168/jds.2015-9736

ZHU X, YAN H, XIA M, X CHANG, XU X, LIU W, SUN X, LU Y, BIAN H, LI X: Metformin attenuates triglyceride accumulation in HepG2 cells through decreasing stearyl-coenzyme A desaturase 1 expression. Lipids Health Dis 17: 1-9, 2018. https://doi.org/10.1186/s12944-018-0762-0 